\title{
Bactericidal and virucidal efficacies of food additive grade calcium hydroxide under various concentrations, organic material conditions, exposure duration, and its stability
}

\author{
Sakchai Ruenphet ${ }^{1}$, Kornkamon Paditporn ${ }^{1}$, Darsaniya Punyadarsaniya ${ }^{1}$, Tippawan Jantafong ${ }^{1}$ and Kazuaki Takehara ${ }^{2}$
}

1. Department of Immunology and Virology, Faculty of Veterinary Medicine, Mahanakorn University of Technology, Bangkok, Thailand; 2. Laboratory of Animal Health, Department of Veterinary Medicine, Faculty of Agriculture, Tokyo University of Agriculture and Technology, Tokyo, Japan.

Corresponding author: Sakchai Ruenphet, e-mail: rsakchai@hotmail.com Co-authors: KP: tu_click@hotmail.com, DP: darsaniya_p@yahoo.de, TJ: jantafong1980@gmail.com, KT: takehara@cc.tuat. ac.jp

Received: 21-05-2019, Accepted: 29-07-2019, Published online: 13-09-2019

doi: 10.14202/vetworld.2019.1383-1389 How to cite this article: Ruenphet S, Paditporn K, Punyadarsaniya D, Jantafong T, Takehara K (2019) Bactericidal and virucidal efficacies of food additive grade calcium hydroxide under various concentrations, organic material conditions, exposure duration, and its stability, Veterinary World, 12(9): 1383-1389.

\begin{abstract}
Aim: This study aimed to evaluate the bactericidal and virucidal activity of food additive grade calcium hydroxide $\left(\mathrm{FdCa}(\mathrm{OH})_{2}\right)$ under various concentrations, organic material conditions, and exposure duration including its stability.

Materials and Methods: The $\mathrm{FdCa}(\mathrm{OH})_{2}$ powder as well as the $0.17 \%$ and $3 \%$ solutions were evaluated for bacteria and virus inactivating efficacies against Salmonella infantis (SI), Escherichia coli, Newcastle disease virus (NDV), and avian influenza virus (AIV), in the absence or presence of organic materials. In addition, the stability of $\mathrm{FdCa}(\mathrm{OH})_{2}$, was also examined using wet-dry conditions and under sunlight.

Results: The $\mathrm{FdCa}(\mathrm{OH})_{2}$ powder could inactivate both NDV and AIV in the absence and presence of organic materials within a 3 min exposure period. The bactericidal efficacy using solution form revealed that $0.17 \%$ and $3 \%$ of $\mathrm{FdCa}(\mathrm{OH})_{2}$ could inactivate $\mathrm{SI}$ in the absence and presence of organic materials within 3 min of exposure. However, $3 \%$ of $\mathrm{FdCa}(\mathrm{OH})_{2}$ inactivated $E$. coli both with and without organic materials within $3 \mathrm{~min}$, while $0.17 \%$ required 5 min to be efficacious. The virucidal efficacy also showed that $0.17 \% \mathrm{FdCa}(\mathrm{OH})_{2}$ could inactivate NDV in the absence and presence of organic materials within $10 \mathrm{~min}$ and $30 \mathrm{~min}$, respectively. However, AIV inactivation was achieved within $30 \mathrm{sec}$ under all conditions. In addition, under wet and dry conditions, $\mathrm{FdCa}(\mathrm{OH})$, powder demonstrated high efficacy when re-suspended at least 16 times for NDV and 7 times for AIV. Simultaneously, the $\mathrm{FdCa}(\mathrm{OH})_{2}$ powder retained its efficacy under the sunlight during up to 4 months for NDV and at least 6 months for AIV.
\end{abstract}

Conclusion: The present study indicates that $\mathrm{FdCa}(\mathrm{OH})_{2}$ powder and solutions could inactivate SI, E. coli, NDV, and AIV while retaining good stability under challenging environmental conditions. Finally, the $\mathrm{FdCa}(\mathrm{OH})_{2}$ is safe for consumers because it is of food additive grade and can be useful as an alternative disinfectant, especially for biosecurity enhancement on and around poultry farms.

Keywords: bactericidal, biosecurity, food additive grade calcium hydroxide, virucidal.

\section{Introduction}

Food-borne diseases causing Escherichia coli and Salmonella spp. are major public health concerns worldwide, especially in the United States, Japan, and Thailand. A variety of foods from animals, such as eggs, meat, and milk, have been implicated as vehicles of one or more of these pathogens in outbreaks of foodborne illness [1]. The U.S. Department of Agriculture, Food Safety, and Inspection Service recommends the Pathogen Reduction Program for antimicrobial treatments, which is a method for reducing or inactivating pathogenic bacteria in foods [2]. The hazard analysis

Copyright: Ruenphet, et al. Open Access. This article is distributed under the terms of the Creative Commons Attribution 4.0 International License (http://creativecommons.org/licenses/ by/4.0/), which permits unrestricted use, distribution, and reproduction in any medium, provided you give appropriate credit to the original author(s) and the source, provide a link to the Creative Commons license, and indicate if changes were made. The Creative Commons Public Domain Dedication waiver (http:// creativecommons.org/publicdomain/zero/1.0/) applies to the data made available in this article, unless otherwise stated. and critical control point (HACCP) has been required for food safety and was introduced at standard farms in Japan. This HACCP will be used for the establishment of critical control points in restaurants, homes, and other foodservice units, including the Olympic games of 2020 in Japan [3]. For animal farms, appropriate HACCP work is necessary to enhance biosecurity, especially in terms of appropriate disinfectants. Several respiratory viruses such as Newcastle disease and bird flu causing Newcastle disease virus (NDV) and avian influenza virus (AIV), have a strong negative impact on the economy of the poultry industry. In general, infected birds are excreted a lot of viruses from the respiratory and gastrointestinal system such as nasal discharge, feces, and leading to transmission and contamination in and around animal farms including human and environment. Hence, instruments of disease control are cleaning and disinfectant applying; however, the efficacy depends on the property of disinfectant and environment condition in animal farm. 
Many disinfectants are available commercially, and it is important to ensure that the disinfectant being used is effective against various pathogens. The modern commercial farms and their environment can provide an appropriate medium for bacteria and virus propagation, while high animal population and short downtimes contribute to high disease incidence [4]. The effective management and husbandry practices are the all-in all-out system [5] and regular cleaning and disinfection, especially before introducing a new flock or herd to the barns [6]. These applications are effective methods to reduce the presence of any bacteria and viruses.

The appropriate disinfectants are critical in establishing a successful sanitation program. Nevertheless, since not all disinfectants are effective against the major pathogens, different families of disinfectants that target specific microorganism should be considered. For instance, several bacteria and viruses are sensitive to phenols, while most bacteria are more sensitive to quaternary ammonium, iodophor, peracetic acid, glutaraldehyde, and cresols [7]. Therefore, there is no one disinfectant reported in the literature that would be efficacious against a wide spectrum of etiological agents of economically impacting diseases in animal farms. Moreover, special care should be taken in the application of the disinfectant, as it should be safe for both animals and humans. In addition, the hardness of water, correct dilutions, contact duration, and the presence of organic material should also be taken into consideration. Several alkaline disinfectants were reported such as ceramic powder [8], nano-sized scallop shell powder [9], scallop shell powder [10], and calcinated eggshell [11]. Nowadays, several forms of calcium hydroxide $\left(\mathrm{Ca}(\mathrm{OH})_{2}\right)$ such as powder form and $0.17 \%$ of $\mathrm{Ca}(\mathrm{OH})_{2}$ solution have been shown to exhibit bactericidal efficacies $[12,13]$ and virucidal efficacies [14,15].

This study aimed to evaluate the efficacy of food additive grade calcium hydroxide $\left(\mathrm{FdCa}(\mathrm{OH})_{2}\right)$ powder, using powder and solution forms against Salmonella infantis (SI), E. coli, NDV, and AIV, in the absence or presence of organic materials, including the stability of $\mathrm{FdCa}(\mathrm{OH})_{2}$ while applied for biosecurity in and around poultry farms.

\section{Materials and Methods \\ Ethical approval} of study.

Ethical approval is not needed to pursue this type

\section{Samples and sample preparation}

The $\mathrm{FdCa}(\mathrm{OH})_{2}$ powder (Fine Co., Ltd., Japan) was used for the present study. The suspension of $\mathrm{FdCa}(\mathrm{OH})_{2}$ was prepared as $0.17 \%$ or $3 \%(\mathrm{w} / \mathrm{v})$ using distilled water and then centrifuged at $3000 \times \mathrm{g}$ for $10 \mathrm{~min}$, the supernatants were used as solution sample in the absence of organic material. The presence of organic material was simulated by adding fetal bovine serum (FBS) as $5 \%$ FBS to the solution sample.

\section{Pathogens, cells, and media}

E. coli and SI provided by Asst. Prof. Dr. Walaiporn Tonpitak (Microbiology section, Mahanakorn Veterinary Diagnostic Center, Veterinary Medicine Faculty, Mahanakorn University of Technology [MUT], Thailand), were used for the present study. These bacteria were sub-cultured onto deoxycholate hydrogen sulfide lactose (DHL) agar and then incubated at $37^{\circ} \mathrm{C}$ overnight. The bacterial colony was picked up and cultivated in Luria-Bertani medium (1\% Bacto Tryptone, $0.5 \%$ Bacto Yeast Extract, and $1 \% \mathrm{NaCl}, \mathrm{pH} 7.4)$ and titrated on DHL agar [11]. Organic materials were removed from bacteria cultures by centrifugation at $1750 \times \mathrm{g}$ for $10 \mathrm{~min}$ before testing. In addition, a virulent NDV, namely, NDV/chicken/Asean Country/2013 [16] and a low pathogenic AIV, namely, A/duck/Asean Country/2004 H9N2 that was provided by Prof. Thaweesak Songserm (Department of Pathology, Faculty of Veterinary Medicine, Kasetsart University), were propagated in 9-day-old chicken embryonic eggs. After allantoic fluid harvesting at 3-day post-inoculation, stock viruses were aliquoted and kept at $-80^{\circ} \mathrm{C}$ until testing. The chicken embryo fibroblasts (CEF) and Madin-Darby canine kidney (MDCK) cells were used for NDV and AIV titration, respectively.

\section{Blocking solution preparation}

The activity of $\mathrm{FdCa}(\mathrm{OH})$, solution was stopped with blocking solution. In the present study, this solution was prepared from $1 \mathrm{M}$ Tris- $\mathrm{HCl} \mathrm{pH} 7.2$ as described [12].

\section{Antimicrobial properties of $\mathrm{FdCa}(\mathrm{OH})_{2}$ powder}

To determine virus inactivation properties of the $\mathrm{FdCa}(\mathrm{OH})_{2}$ powder, $200 \mathrm{mg}$ of $\mathrm{FdCa}(\mathrm{OH})_{2}$ powder was mixed with $100 \mu 1$ of NDV or AIV in the absence of organic materials. The efficacy of the same powder was then evaluated in the presence of organic material simulated using FBS as virus containing 33\% of organic materials. Briefly, $100 \mu \mathrm{l}$ of each virus was mixed with $50 \mu \mathrm{l}$ of FBS, and then added all mixed to $300 \mathrm{mg}$ of $\mathrm{FdCa}(\mathrm{OH})_{2}$ powder. After 3 min incubation at room temperature, the viruses were recovered using phosphate-buffered saline (PBS) and titrated onto CEF or MDCK cells, respectively [11].

\section{Antimicrobial properties of $\mathrm{FdCa}(\mathrm{OH})_{2}$ solution}

Four hundred microliters of each $\mathrm{FdCa}(\mathrm{OH})_{2}$ solution sample were mixed with $100 \mu \mathrm{l}$ of each pathogen, then incubated at room temperature for $5 \mathrm{~s}, 30 \mathrm{~s}$, $1 \mathrm{~min}, 3 \mathrm{~min}, 5 \mathrm{~min}, 10 \mathrm{~min}, 30 \mathrm{~min}$, or $1 \mathrm{~h}$. After that, the solution mixture was neutralized with $500 \mu 1$ of blocking solution, and then titrated onto MDCK cells and CEF for AIV and NDV, respectively, or onto DHL agar Petri dish for both bacteria. To simulate the presence of organic materials, $500 \mu \mathrm{l}$ of FBS was added to $10 \mathrm{ml}$ of each $\mathrm{FdCa}(\mathrm{OH})_{2}$, solution sample to represent $5 \%$ organic material, before testing. To confirm the neutralizing efficacy of Tris- $\mathrm{HCl}$, it was added into each solution sample before adding virus or bacteria, namely, at $0 \mathrm{~s}$. Each treatment was conducted 
in triplicates, and the titers were expressed as means with standard error (SE).

\section{Stability under sunlight and wet-dry condition}

The stability of $\mathrm{FdCa}(\mathrm{OH})_{2}$ powder stored under harsh conditions was also evaluated for its virucidal activity using NDV and AIV. A quantity of $3 \mathrm{~g}$ of $\mathrm{FdCa}(\mathrm{OH})_{2}$, powder in a 90-mm Petri dish was kept under sunlight for 6 months. Another batch of $\mathrm{FdCa}(\mathrm{OH})$, powder was used for making suspensions in $10 \mathrm{ml}$ of distilled water, and the dish was kept until completely dried in $37^{\circ} \mathrm{C}$ incubator. Re-suspension and drying were repeated up to 16 times or until virucidal efficacy losing [9].

\section{Virus and bacteria titration and calculation}

Each E. coli and SI treatment was diluted as 10-fold serial dilution using PBS and inoculated onto DHL agar for bacterial titration. All inoculated Petri dishes were incubated at $37^{\circ} \mathrm{C}$ incubator, and the number of colonies was recorded at 24-h post-inoculation. The bacteria titer was calculated in colony-forming units/ml. In addition, NDV and AIV treated samples were diluted as 10-fold serial dilution using Eagle's minimum essential medium (MEM, Nissui Pharmaceutical Co., Ltd., Tokyo, Japan) containing $0.3 \%$ of tryptose phosphate broth, penicillin 100 units $/ \mathrm{ml}$, streptomycin $100 \mu \mathrm{g} / \mathrm{ml}$, amphotericin B $0.5 \mu \mathrm{g} / \mathrm{ml}$, and $4 \mathrm{mM} \mathrm{L-glutamine}$ and inoculated onto $\mathrm{CEF}$ or $\mathrm{MDCK}$, respectively. However, before inoculation, trypsin (Trypsin, Sigma, St. Louis, MO, USA), at the final concentration of $0.2 \mu \mathrm{g} / \mathrm{ml}$ was added to MEM. All of inoculated tissue culture plates were incubated at $37^{\circ} \mathrm{C}$ in $5 \% \mathrm{CO}_{2}$ incubator and observed for cytopathic effect (CPE) twice a day for 3 days. At the end of the incubation period, the hemagglutinin activity of the culturing supernatant was detected using $0.5 \%$ chicken red blood cells. Finally, the 50\% tissue culture infective dose/ml was determined by Behrens and Kärber's method [9].

\section{Inactivation analysis}

The reduction factor (RF) was used for determining the bacteria or virus inactivation. The RF was calculated using the following equation $R F=t_{p c}-t_{a}$; where $t_{p c}$ is the titer converted into an index in $\log _{10}$ of the positive control, and $t_{a}$ is the converted titer an index in $\log _{10}$ of the recovered bacteria or virus from the treated sample. Bacteria or virus inactivation was considered effective when RF was greater than or equal to $3 \log _{10}$ [17-19].

\section{Statistical analysis}

In the present study, the RF was analyzed independently and shown as mean \pm SE. The one-way analysis of variance post hoc test (SPSS, Armonk, NY, USA) was performed to determine the statistical significance of differences in $\mathrm{FdCa}(\mathrm{OH})_{2}$ efficacy between the positive control and also among the treatment group. A significant difference was noticed while the associated $\mathrm{p}<0.05$.

\section{Results}

\section{Virucidal efficacy using the powder form}

The inactivating efficacy of the $\mathrm{FdCa}(\mathrm{OH})_{2}$ powder is shown in Table-1. $\mathrm{FdCa}(\mathrm{OH})_{2}$ powder could inactivate both NDV and AIV in the absence of organic material, with the RF being $>5.17 \pm 0.88$ and $>3.75 \pm 0.25$, respectively, and in the presence of organic materials being $4.58 \pm 1.28$ and $>4.00 \pm 0.25$, respectively (Table-1).

\section{Bactericidal efficacy using solution form}

Table-2 shows the bactericidal efficacy of $\mathrm{FdCa}(\mathrm{OH})_{2}$ solution against $\mathrm{SI}$ and $E$. coli in the absence or presence of organic materials. Both $0.17 \%$ and $3 \%$ of $\mathrm{FdCa}(\mathrm{OH})_{2}$, solution could inactivate $\mathrm{SI}$ in the absence and presence of organic materials within 3 min; nevertheless, only $3 \%$ of $\mathrm{FdCa}(\mathrm{OH})_{2}$ solution could inactivate $E$. coli - regardless of the presence or absence of organic materials - within 3 min. However, the $0.17 \%$ solution requires $5 \mathrm{~min}$ to inactivate the E. coli.

\section{Virucidal efficacy using solution form}

The virucidal efficacy of $\mathrm{FdCa}(\mathrm{OH})$, solution against NDV and AIV is depicted in Table-3. At $0.17 \%$ of $\mathrm{FdCa}(\mathrm{OH})_{2}$, solution could inactivate NDV in the absence and presence of organic material within $10 \mathrm{~min}$ and $30 \mathrm{~min}$, respectively. Conversely, AIV was inactivated within $30 \mathrm{sec}$, regardless of the presence and absence of organic materials.

\section{Stability of $\mathrm{FdCa}(\mathrm{OH})_{2}$}

Results depicting the outcome of the evaluation of $\mathrm{FdCa}(\mathrm{OH})_{2}$ powder kept under conditions simulating a harsh environment such as wet and dry conditions and under sunlight, as shown in Tables-4 and 5. Even under wet and dry conditions, $\mathrm{Ca}(\mathrm{OH})_{2}$ powder demonstrated high efficacy when re-suspended

Table-1: The results are presented as $\log _{10} \mathrm{TCID}_{50} / \mathrm{ml}(\mathrm{mean} \pm \mathrm{SE})$ of Newcastle disease virus and avian influenza virus inactivating efficacy, using food additive grade calcium hydroxide powder, in the absence or presence of organic materials.

\begin{tabular}{lcccccccc}
\hline \multirow{2}{*}{ Organic materials } & \multicolumn{3}{c}{ Newcastle disease virus } & & \multicolumn{3}{c}{ Avian influenza virus } \\
\cline { 2 - 3 } & Treated & Control & RF & & Treated & Control & RF \\
\hline $0 \%$ & $<2.50 \pm 0.00$ & $7.67 \pm 0.88$ & $>5.17 \pm 0.88^{*}$ & & $<2.50 \pm 0.00$ & $6.25 \pm 0.25$ & $>3.75 \pm 0.25^{*}$ \\
$33 \%$ & $<2.50 \pm 0.00$ & $7.08 \pm 1.28$ & $>4.58 \pm 1.28^{*}$ & & $<2.50 \pm 0.00$ & $6.50 \pm 0.25$ & $>4.00 \pm 0.25 *$ \\
\hline
\end{tabular}

${ }^{\mathrm{a}} \mathrm{RF}=$ Reduction factor, $*$ Inactivation regarded as effective when RF was $\geq 3 \log _{10} . \mathrm{TCID}_{50}=50 \%$ tissue culture infective dose 
Table-2: The results are presented as $\log _{10} \mathrm{CFU} / \mathrm{ml}$ (mean $\pm \mathrm{SE}$ ) of Salmonella infantis and E. coli inactivating efficacy, using $0.17 \%$ and $3 \%$ of food additive grade calcium hydroxide solution, in the absence or presence of organic materials.

\begin{tabular}{|c|c|c|c|c|c|c|c|c|}
\hline \multirow[t]{3}{*}{ Conditions } & \multicolumn{4}{|c|}{ Salmonella infantis } & \multicolumn{4}{|c|}{ E. coli } \\
\hline & \multicolumn{2}{|c|}{$0.17 \%$} & \multicolumn{2}{|c|}{$3 \%$} & \multicolumn{2}{|c|}{$0.17 \%$} & \multicolumn{2}{|c|}{$3 \%$} \\
\hline & 0\% FBS & $5 \%$ FBS $^{a}$ & 0\% FBS & $5 \%$ FBS & 0\% FBS & $5 \%$ FBS & 0\% FBS & $5 \%$ FBS \\
\hline $\mathrm{tpc}^{\mathrm{b}}$ & $8.65 \pm 0.19$ & $8.65 \pm 0.19$ & $8.65 \pm 0.19$ & $8.65 \pm 0.19$ & $9.10 \pm 0.19$ & $9.10 \pm 0.19$ & $9.10 \pm 0.19$ & $9.10 \pm 0.19$ \\
\hline $0 \mathrm{~s}^{\mathrm{c}}$ & $8.85 \pm 0.51$ & $8.70 \pm 0.17$ & $8.67 \pm 0.20$ & $8.69 \pm 0.14$ & $9.09 \pm 0.45$ & $8.84 \pm 0.25$ & $8.94 \pm 0.31$ & $8.75 \pm 0.32$ \\
\hline $1 \min ^{d}$ & $6.73 \pm 0.66$ & $6.66 \pm 0.52$ & $6.38 \pm 0.38$ & $6.30 \pm 0.48$ & $7.60 \pm 0.00$ & $7.60 \pm 0.00$ & $7.60 \pm 0.00$ & $7.44 \pm 0.29$ \\
\hline $3 \mathrm{~min}$ & $2.70 \pm 0.17 *$ & $3.25 \pm 0.75^{*}$ & $3.38 \pm 1.34 *$ & $3.51 \pm 1.58 *$ & $6.57 \pm 0.49$ & $6.96 \pm 0.36$ & $4.51 \pm 0.27 *$ & $5.31 \pm 0.41 *$ \\
\hline $5 \min$ & $2.60 \pm 0.00 *$ & $2.70 \pm 0.17 *$ & $2.60 \pm 0.00 *$ & $2.60 \pm 0.00 *$ & $3.81 \pm 1.05 *$ & $4.24 \pm 1.44 *$ & $2.60 \pm 0.00 *$ & $2.60 \pm 0.00 *$ \\
\hline
\end{tabular}

${ }^{\mathrm{a}} \mathrm{Fetal}$ bovine serum was added to $\mathrm{FdCa}(\mathrm{OH})_{2}$ solution so as to represent $5 \%$ organic materials of total volume. ${ }^{\mathrm{b}} \mathrm{The}$ titer converted into an index in $\log _{10}$ of bacteria control. ${ }^{c}$ The titer in $\log _{10}$ that added blocking solution before Salmonella infantis or $E$. coli. dThe titer converted into an index in $\log _{10}$ of the recovered bacteria after indicated time of treatment, such as $1 \mathrm{~min}, 3 \mathrm{~min}$, and $5 \mathrm{~min}$. *Inactivation regarded as effective when RF was $\geq 3$. E. coli=Escherichia coli, $\mathrm{RF}=$ Reduction factor, $\mathrm{CFU}=$ Colony-forming units, $\mathrm{tpc}=$ Titer of bacteria/virus control, $\mathrm{FBS}=\mathrm{Fetal}$ bovine serum, FdCa $(\mathrm{OH})_{2}=$ Food additive grade calcium hydroxide

Table-3: The results are presented as $\log _{10} \mathrm{TCID}_{50} / \mathrm{ml}($ mean $\pm \mathrm{SE})$ of Newcastle disease virus and avian influenza virus inactivating efficacy, using $0.17 \%$ and $3 \%$ of food additive grade calcium hydroxide solution, in the absence or presence of organic materials.

\begin{tabular}{|c|c|c|c|c|c|c|c|c|}
\hline \multirow[t]{3}{*}{ Conditions } & \multicolumn{4}{|c|}{ Newcastle disease virus } & \multicolumn{4}{|c|}{ Avian influenza virus } \\
\hline & \multicolumn{2}{|c|}{$0.17 \%$} & \multicolumn{2}{|c|}{$3 \%$} & \multicolumn{2}{|c|}{$0.17 \%$} & \multicolumn{2}{|c|}{$3 \%$} \\
\hline & 0\% FBS & $5 \%$ FBS $^{a}$ & 0\% FBS & $5 \%$ FBS & 0\% FBS & $5 \%$ FBS & 0\% FBS & $5 \%$ FBS \\
\hline $\mathrm{tpc}^{\mathrm{b}}$ & $8.13 \pm 0.43$ & $8.25 \pm 0.47$ & $8.13 \pm 0.43$ & $8.13 \pm 0.43$ & $6.50 \pm 0.35$ & $6.50 \pm 0.35$ & $6.31 \pm 0.31$ & $6.31 \pm 0.31$ \\
\hline $0 \mathrm{~s}^{c}$ & $8.17 \pm 0.38$ & $8.25 \pm 0.66$ & $8.08 \pm 0.29$ & $8.00 \pm 0.50$ & $6.25 \pm 0.43$ & $6.50 \pm 0.50$ & $6.19 \pm 0.72$ & $6.50 \pm 0.58$ \\
\hline $5 \mathrm{~s}^{\mathrm{d}}$ & $\mathrm{NT}^{\mathrm{e}}$ & NT & NT & NT & $3.92 \pm 0.76$ & $4.00 \pm 0.25$ & $3.33 \pm 1.04$ & $3.33 \pm 1.44$ \\
\hline $30 \mathrm{~s}$ & NT & NT & NT & NT & $2.92 \pm 0.52 *$ & $2.50 \pm 0.00 *$ & $2.92 \pm 0.29 *$ & $2.50 \pm 0.00 *$ \\
\hline $1 \mathrm{~min}$ & NT & NT & NT & NT & NT & NT & NT & NT \\
\hline $5 \mathrm{~min}$ & $5.63 \pm 0.18$ & $6.13 \pm 0.53$ & $5.25 \pm 0.00$ & $5.38 \pm 0.18$ & NT & NT & NT & NT \\
\hline $10 \mathrm{~min}$ & $4.67 \pm 0.14 *$ & $5.83 \pm 0.76$ & $4.75 \pm 0.25^{*}$ & $5.00 \pm 0.66 *$ & NT & NT & NT & NT \\
\hline $30 \mathrm{~min}$ & $4.13 \pm 0.88^{*}$ & $5.08 \pm 0.29 *$ & $4.25 \pm 0.71^{*}$ & $4.25 \pm 1.06 *$ & NT & NT & NT & NT \\
\hline $1 \mathrm{~h}$ & NT & $4.75 \pm 0.00 *$ & NT & NT & NT & NT & NT & NT \\
\hline
\end{tabular}

a Fetal bovine serum was added to $\mathrm{FdCa}(\mathrm{OH})_{2}$ solution so as to represent $5 \%$ organic materials of total volume. ${ }^{\mathrm{b}} \mathrm{The}$ titer converted into an index in $\log _{10}$ of virus control. ${ }^{T}$ The titer in $\log _{10}$ while adding blocking solution before Newcastle disease

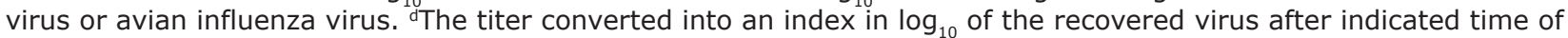
treatment, such as $5 \mathrm{~s}, 30 \mathrm{~s}, 1 \mathrm{~min}, 5 \mathrm{~min}, 10 \mathrm{~min}, 15 \mathrm{~min}, 30 \mathrm{~min}$, and $1 \mathrm{~h}$. eNT=Not tested. *Inactivation regarded as effective when RF was $\geq 3$. tpc $=$ Titer of bacteria/virus control, FBS=Fetal bovine serum, FdCa $(\mathrm{OH})_{2}=$ Food additive grade calcium hydroxide

Table-4: Efficacy of food additive calcium grade hydroxide powder for inactivating Newcastle disease virus and avian influenza virus under wet and dry conditions at consecutive re-suspension times, with a 3-min incubation period.

\begin{tabular}{|c|c|c|c|c|c|c|}
\hline \multirow[t]{2}{*}{ Number of resuspension } & \multicolumn{3}{|c|}{ Newcastle disease virus } & \multicolumn{3}{|c|}{ Avian influenza virus } \\
\hline & Treated & Control & $\mathbf{R F}^{\mathbf{a}}$ & Treated & Control & $\mathbf{R F}$ \\
\hline 1 & $<2.50$ & 8.25 & $>5.75^{*}$ & $<2.50$ & 6.00 & $>3.50 *$ \\
\hline 2 & $<2.50$ & 8.25 & $>5.75^{*}$ & $<2.50$ & 6.00 & $>3.50 *$ \\
\hline 3 & $<2.50$ & 8.25 & $>5.75^{*}$ & $<2.50$ & 6.00 & $>3.50 *$ \\
\hline 4 & $<2.50$ & 8.25 & $>5.75^{*}$ & $<2.50$ & 6.00 & $>3.50 *$ \\
\hline 5 & $<2.50$ & 8.25 & $>5.75^{*}$ & $<2.50$ & 6.00 & $>3.50 *$ \\
\hline 6 & $<2.50$ & 8.25 & $>5.75^{*}$ & 3.50 & 6.50 & $3.00 *$ \\
\hline 7 & $<2.50$ & 8.25 & $>5.75^{*}$ & 3.25 & 6.25 & $3.00 *$ \\
\hline 8 & $<2.50$ & 8.25 & $>5.75^{*}$ & 3.50 & 6.25 & 2.75 \\
\hline 9 & 5.25 & 8.75 & $3.50 *$ & 3.50 & 6.25 & 2.75 \\
\hline 10 & 5.00 & 8.75 & $3.75 *$ & 4.00 & 6.25 & 2.25 \\
\hline 11 & 5.25 & 8.75 & $3.50 *$ & $\mathrm{NT}^{\mathrm{b}}$ & NT & NT \\
\hline 12 & 5.00 & 8.75 & $3.75^{*}$ & NT & NT & NT \\
\hline 13 & 5.25 & 8.75 & $3.50 *$ & NT & NT & NT \\
\hline 14 & 5.50 & 8.75 & $3.25 *$ & NT & NT & NT \\
\hline 15 & 5.50 & 8.75 & $3.25 *$ & NT & NT & NT \\
\hline 16 & 5.25 & 8.75 & $3.50 *$ & NT & NT & NT \\
\hline
\end{tabular}

${ }^{\mathrm{a}} \mathrm{RF}=$ Reduction factor, ${ }^{\mathrm{b}} \mathrm{NT}=$ Not tested. $*$ Inactivation regarded as effective when RF was $\geq 3$ 
Table-5: Efficacy of food additive grade calcium hydroxide powder at consecutive time points for inactivating Newcastle disease virus and avian influenza virus under sunlight, during a 3-min incubation period.

\begin{tabular}{|c|c|c|c|c|c|c|}
\hline \multirow[t]{2}{*}{ Month } & \multicolumn{3}{|c|}{ Newcastle disease virus } & \multicolumn{3}{|c|}{ Avian influenza virus } \\
\hline & Treated & Control & $\mathbf{R F}^{\mathbf{a}}$ & Treated & Control & RF \\
\hline 1 & $<2.50$ & 8.75 & $>6.25^{*}$ & $<2.50$ & 6.25 & $>3.75^{*}$ \\
\hline 2 & $<2.50$ & 8.75 & $>6.25^{*}$ & $<2.50$ & 6.25 & $>3.75^{*}$ \\
\hline 3 & $<2.50$ & 8.75 & $>6.25^{*}$ & $<2.50$ & 6.25 & $>3.75^{*}$ \\
\hline 4 & $<2.50$ & 7.50 & $>5.00 *$ & $<2.50$ & 6.25 & $>3.75^{*}$ \\
\hline 5 & 7.25 & 7.50 & 0.25 & $<2.50$ & 6.25 & $>3.75^{*}$ \\
\hline 6 & 6.25 & 7.50 & 1.25 & $<2.50$ & 6.25 & $>3.75^{*}$ \\
\hline
\end{tabular}

${ }^{\mathrm{a}} \mathrm{RF}=$ Reduction factor, $*$ Inactivation regarded as effective when RF was $\geq 3$

Table-6: Properties and ingredients of $\mathrm{FdCa}(\mathrm{OH})_{2}$ powder.

\begin{tabular}{|c|c|c|c|}
\hline $\mathrm{FdCa}(\mathrm{OH})_{2}$ & \multicolumn{3}{|l|}{ Properties } \\
\hline Appearance & \multicolumn{3}{|c|}{$\begin{array}{l}\text { White or ashy white color powder and } \\
\text { granules }\end{array}$} \\
\hline $\mathrm{pH}$ & \multicolumn{3}{|c|}{$12.4\left(25^{\circ} \mathrm{C}\right.$ saturated solution) } \\
\hline Specific gravity & \multicolumn{3}{|c|}{2.24} \\
\hline Solubility & \multicolumn{3}{|c|}{$\begin{array}{l}\text { Dissolves in water } \\
\text { Saturated solution forms as } 0.17 \\
\mathrm{~g} / 100 \mathrm{cc}\end{array}$} \\
\hline $\begin{array}{l}\text { Resolution } \\
\text { temperature }\end{array}$ & \multicolumn{3}{|c|}{$580^{\circ} \mathrm{C}$} \\
\hline & \multicolumn{3}{|c|}{$\begin{array}{l}\text { Outside based on } \mathrm{LD}_{50}: 7340 \mathrm{mg} / \mathrm{kg} \\
\text { within the rat } \\
\text { Skin corrosive and circumstantial } \\
\text { inflammation } \\
\text { Severe damage and stimulate toward } \\
\text { eyes }\end{array}$} \\
\hline Ingredients & $\begin{array}{l}\text { Chemical } \\
\text { formula }\end{array}$ & Ingredient & $\begin{array}{l}\text { Standard } \\
\text { slaked lime }\end{array}$ \\
\hline $\begin{array}{l}\text { Calcium hydroxide } \\
\text { Carbonate object } \\
\text { Hydrochloric acid } \\
\text { insoluble }\end{array}$ & $\mathrm{Ca}(\mathrm{OH})_{2}$ & $\begin{array}{l}97.06 \% \\
\text { Clear } \\
\text { Clear } \\
0.01 \%\end{array}$ & $\begin{array}{l}>95.0 \% \\
\text { Non-bubble } \\
<0.50 \%\end{array}$ \\
\hline Heavy metals & & Clear & \\
\hline $\begin{array}{l}\text { Alkali metal and } \\
\text { magnesium }\end{array}$ & $\mathrm{Mg}$ & $\begin{array}{l}\text { Clear } \\
0.56 \%\end{array}$ & $<6.0 \%$ \\
\hline Barium & $\mathrm{Ba}$ & Clear & $<0.03 \%$ \\
\hline Arsenic & $\mathrm{As}_{2} \mathrm{O}_{3}$ & Clear 0.08 & $<4 \mu \mathrm{g} / \mathrm{g}$ \\
\hline
\end{tabular}

FdCa $(\mathrm{OH})_{2}=$ Food additive grade calcium hydroxide

$\geq 16$ times for NDV and 7 times for AIV (Table-4). The viral titer was reduced to below the detection limit using the $\mathrm{FdCa}(\mathrm{OH})_{2}$ powder that was re-suspended 8 times for NDV, and 5 times for AIV. In addition, the $\mathrm{FdCa}(\mathrm{OH})_{2}$ powder was also shown to be able to retain its efficacy under sunlight for up to 4 months for NDV and at least 6 months for AIV (Table-5).

\section{Discussion}

Titer of bacteria/virus control and $0 \mathrm{~s}$ did not show marked inactivation difference; these results indicated that the efficacy of blocking solution could neutralize the inactivation activity of $\mathrm{FdCa}(\mathrm{OH})_{2}$. This blocking solution was used as an instrument for the determination of contact time in the present study. Sonthipet et al. [20] also used $1 \mathrm{M}$ Tris-HCl as blocking solution for exposure time determination to bactericidal and virucidal efficacies of potassium monopersulfate. The present study suggests that the inactivating mechanism of $\mathrm{FdCa}(\mathrm{OH})_{2}$ might be associated with high alkalinity.

This $\mathrm{FdCa}(\mathrm{OH})$, is made from Japanese marine limestone through calcination process, with an average diameter of the powder particle size being $10 \mu \mathrm{m}$. This product is produced at a high quality level in terms of high concentration and the smallest particle of calcium hydroxide $\left(\mathrm{Ca}(\mathrm{OH})_{2}\right)$ [12,13,21]. In general, the properties of $\mathrm{Ca}(\mathrm{OH})_{2}$ were similar to slaked lime (SL) that is made from limestone, which is an inorganic compound with the chemical formula $\mathrm{Ca}(\mathrm{OH})_{2}$. Table- 6 shows the properties and ingredients of $\mathrm{FdCa}(\mathrm{OH})_{2}$, including standard SL; $\mathrm{FdCa}(\mathrm{OH})_{2}$ is a colorless crystal or white powder, and the main ingredient of $\mathrm{Ca}(\mathrm{OH})_{2}$ and $\mathrm{SL}$, as $97.06 \%$ and $95 \%$, respectively. Both $\mathrm{FdCa}(\mathrm{OH})_{2}$ and SL have high alkalinity $(\sim \mathrm{pH} 12.5)$. The present study indicated that $\mathrm{FdCa}(\mathrm{OH})_{2}$ powder could inactivate NDV in the absence and presence of organic materials, which harmonized with several researchers such as Thammakarn et al. [10], who reported that alkaline agents such as scallop-shell powder and SL have high alkalinity and excellent ability to inactivate viruses such as AIV. Lorcharoenrungroj et al. [22] and Paditporn et al. [16] also reported alkaline agents, such as fresh charcoal ash and SL, that could inactivate bacteria and viruses. In addition, the SL is effects toward consumers and animals such as irritation of skin, eyes, and respiratory inflammation. However, $\mathrm{FdCa}(\mathrm{OH})_{2}$ induces these clinical signs less than SL.

In general, the SL or calcium hydroxide could dissolve in water and dissociate into $\mathrm{Ca}^{++}$, and $\mathrm{OH}^{-}$, resulting in a solution with high alkalinity. This solution has a $\mathrm{pH}$ of greater than 9 due to the $(\mathrm{OH})^{-}$and this is postulated to be the main mechanism of antimicrobial activity against bacteria and viruses [23]. However, the solubility of $\mathrm{FdCa}(\mathrm{OH})$, is lower than SL, as $0.17 \%$ and $0.185 \%$, respectively. The present study revealed that both $0.17 \%$ and $3 \%$ of $\mathrm{FdCa}(\mathrm{OH})_{2}$ solution in the absence or presence of organic materials, did not show inactivation differences. These results confirmed that $0.17 \%$ represents a saturated solution, which is sufficient for bactericidal and virucidal activities.

Normally, the survival of various viruses, especially AIV, is affected by different physical and 
chemical conditions, such as temperature, $\mathrm{pH}, \mathrm{UV}$, detergent, and salinity [24-26]. These viruses can survive for several months to a year in the optimal environment, especially in water [1], including at low environmental temperatures [27]. Several viruses are stable at a slightly basic $\mathrm{pH}$ (7.4-8.2) such as AIV [24]. However, viruses are considered to be sensitive to acidic or high alkaline conditions, including low-pathogenic and highly-pathogenic AIVs [25-29]. The high $\mathrm{pH}$ of $\mathrm{FdCa}(\mathrm{OH})_{2}$ in the present study also revealed that $\mathrm{FdCa}(\mathrm{OH})_{2}$ could inactivate bacteria and viruses even at high $\mathrm{pH}$ condition and could not inactivate due to neutralizing by Tris- $\mathrm{HCl}$.

Finally, under harsh conditions, the $\mathrm{FdCa}(\mathrm{OH})_{2}$ powder could inactivate both viruses. This experiment simulates real environmental conditions such as under sunlight condition and provides factors of heat, ultraviolet radiation, and dryness. Similarly, emulating summer season, including, wet and dry conditions, was conducted by soaking in water and then drying thoroughly, which resembles rain soaking in the rainy season. These conditions are very important for disinfectant applying in and around animal farms, especially the frequency of using in each season.

\section{Conclusion}

The present study showed that $\mathrm{FdCa}(\mathrm{OH})$, either in powder and solution forms, has good antimicrobial properties against SI, E. coli, NDV, and AIV when used at the right dosage and exposure time. The $\mathrm{FdCa}(\mathrm{OH})_{2}$ is not only efficacious regardless of the presence or absence of organic materials but it is also stable under the harsh conditions simulated in this study. Finally, the $\mathrm{FdCa}(\mathrm{OH})_{2}$ is safe for consumers because it is of food additive grade and can be useful as an alternative disinfectant, especially for biosecurity enhancement in and around poultry farms.

\section{Authors' Contributions}

SR and KP carried out the main research works and analyzed the main data in the experiments. DP, $\mathrm{TJ}$, and KT have supervised the laboratory work and approved the final version of the manuscript. All authors read and approved the final manuscript.

\section{Acknowledgments}

The authors would like to thank Fine Co., Ltd. (Japan) for $\mathrm{FdCa}(\mathrm{OH})_{2}$ powder provided for this study, as well as Dr. Dany Shoham, Bar Ilan University, Israel, for the grammatical review of the manuscript. We also thank Prof. Thaweesak Songserm and Asst. Prof. Dr. Walaiporn Tonpitak from the Department of Pathology, Faculty of Veterinary Medicine, Kasetsart University, and Mahanakorn Veterinary Diagnostic Center, Veterinary Medicine Faculty, Mahanakorn University of Technology, Thailand, who provided Newcastle disease virus, avian influenza virus, Escherichia coli and Salmonella Infantis for this experiment. The present study was supported in part by grant in aid from Mahanakorn University of Technology, Thailand.

\section{Competing Interests}

The authors declare that they have no competing interests.

\section{Publisher's Note}

Veterinary World remains neutral with regard to jurisdictional claims in published institutional affiliation.

\section{References}

1. Doyle, M.P., Zhao, T., Meng, J. and Zhao, S. (1997) Escherichia coli O157 H7-Food Microbiology Fundamentals and Frontiers. American Society for Microbiology, Washington DC, USA.

2. Food Safety and Inspection Service, Department of Agriculture. (1996) Pathogen Reduction Hazard Analysis and Critical Control Point (HACCP) Systems. Available from https//www.fsis.usda.gov/wps/wcm/connect/e113b15a837c-46af-8303-73f7c11 fb666/93-016F.pdf?MOD=AJPERES. Last accessed on 25-07-2019.

3. Ministry of Agriculture Forestry and Fisheries. (2017) The Improvement of the Breeding Hygiene Management Standard in the Stage of Production of the Domestic Animal. Available from http//www.maff.go.jp/j/syouan/ douei/katiku_yobo/k_haccp/index.html. Last accessed on 20-02-2017.

4. Ruano, M., El-Attrache J. and Villegas, P. (2001). Efficacy comparisons of disinfectants used by the commercial poultry industry. Avian Dis., 45(4): 972-977.

5. Wierup, M. (2000) The control of microbial diseases in animals Alternatives to use of antibiotics. Int. J. Antimicrob. Agents, 14(4): 315-319.

6. Doerning, B.J. (1998) Sanitation Concerns. In Proceeding of the $135^{\text {th }}$ Annual Meeting of the American Veterinary Medical Association. The American Veterinary Medical Association, Illinois, USA. p162-164.

7. Bermudez, A.J. (2008) Principles of disease prevention Diagnosis and control. In Diseases of Poultry. $12^{\text {th }}$ ed. Blackwell Publishing, Iowa, USA. p3-42.

8. Takehara, K., Chinen, O., Jahangir, A., Miyoshi, Y., Ueno, Y., Ueda, S., Takada, Y., Ruenphet, S., Mutoh, K., Okamura, M. and Nakamura, M. (2009) Ceramic powder made from chicken feces Anti-viral effects against avian influenza viruses. Avian Dis., 53(1): 34-38.

9. Thammakarn, C., Satoh, K., Suguro, A., Hakim, H., Ruenphet, S. and Takehara, K. (2014) Inactivation of avian influenza virus, Newcastle disease virus and goose parvovirus using solution of nano-sized scallop shell powder. J. Vet. Med. Sci., 76(9): 1277-1280.

10. Thammakarn, C., Tsujimura, M., Satoh, K., Hasegawa, T., Tamura, M., Kawamura, A., Ishida, Y., Suguro, A., Hakim, H., Ruenphet, S. and Takehara, K. (2015a) Efficacy of scallop shell powders and slaked lime for inactivating avian influenza virus under harsh conditions. Arch. Virol., 160(7): 2577-2581.

11. Ota, M., Yamada, M., Nakajima, K., Kitazawa, M., Hakim, H., Alam, Md. S., Shoham, D. and Takehara, K. (2016) Calcinated eggshell as a candidate of biosecurity enhancement material. J. Vet. Med. Sci., 78(5): 831-836.

12. Hakim, H., Toyofuku, C., Ota, M., Suzuki, M., Komura, M., Yamada, M., Alam, M.S., Sangsriratanakul, N., Shoham, D. and Takehara, K. (2017a) Accuracy of the evaluation method for alkaline agents' bactericidal efficacies in solid, and the required time of bacterial inactivation. J. Vet. Med. Sci., 79(2): 244-247.

13. Hakim, H., Toyofuku, C., Ota, M., Suzuki, M., Komura, M., 
Yamada, M., Alam, M.S., Sangsriratanakul, N., Shoham, D. and Takehara, K. (2017b) Durability of alkaline agents' bactericidal efficacies in litter under field conditions. J. Vet. Med. Sci., 79(5): 815-817.

14. Ito, M., Alam, M.S., Suzuki, M., Takahashi, S., Komura, M., Sangsriratakul, N., Shoham, D. and Takehara, K. (2018) Virucidal activity of a quaternary ammonium compound associated with calcium hydroxide on avian influenza virus, Newcastle disease virus, and infectious bursal disease virus. J. Vet. Med. Sci., 80(4): 574-577.

15. Sangsriratanakul, N., Toyofuku, C., Suzuki, M., Komura, M., Yamada, M., Alam, Md. S, Ruenphet, S., Shoham, D., Sakai, K. and Takehara, K. (2018) Virucidal efficacy of food additive grade calcium hydroxide against surrogate of human norovirus. J. Virol. Methods, 251: 83-87.

16. Paditporn, K., Ruenphet, S. and Takehara, K. (2016) Comparison of virucidal effects for the newcastle disease virus between slaked lime and food additive calcium hydroxide. In Proceedings of the $9^{\text {th }}$ MUT Veterinary Annual Conference 2016, Mahanakorn University of Technology, Bangkok, Thailand. p13-18.

17. Lombardi, M.E., Ladman, B.S., Alphin, R.L. and Benson, E.R. (2008). Inactivation of avian influenza virus using common detergents and chemicals. Avian Dis., 52(1): 118-123.

18. Takehara, K., Yamazaki, K., Miyazaki, M., Yamada, Y., Ruenphet, S., Jahangir, A., Shoham, D., Okumura, M. and Nakamura, M. (2010) Inactivation of avian influenza virus H1N1 by photocatalyst under visible light irradiation. Virus Res., 151(1): 102-103.

19. Thammakarn, C., Ishida, Y., Suguro, A., Hakim, H., Nakajima, K., Kitazawa, M. and Takehara, K. (2015b) Inhibition of infectious bursal disease virus transmission using bioceramic derived from chicken feces. Virus Res., 204: 6-12.

20. Sonthipet, S., Ruenphet, S. and Takehara, K. (2018) Bactericidal and virucidal efficacies of potassium monopersulfate and its application for inactivating avian influenza virus on virus-spiked clothes. J. Vet. Med. Sci., 80(4): 568-573.
21. Toyofuku, C., Alam, M.S., Yamada, M., Komura, M., Suzuki, M., Hakim, H., Sangsriratanakul, N., Shoham, D. and Takehara, K. (2017) Enhancement of bactericidal effects of sodium hypochlorite in chiller water with food additive grade calcium hydroxide. J. Vet. Med. Sci., 79(6): 1019-1023.

22. Lorcharoenrungroj, K., Takehara, K. and Ruenphet, S. (2016) Studies on Fresh Charcoal ash to Inactivate Avian Influenza Virus, Escherichia coli and Salmonella Infantis for Biosecurity Enhancement on Chicken Farms. In Proceedings of the $9^{\text {th }}$ MUT Veterinary Annual Conference 2016, Mahanakorn University of Technology, Bangkok, Thailand. p5-12.

23. Aiello, S. (1998) The Merck Veterinary Manual. $8^{\text {th }}$ ed. Merck and Co., Whitehouse Station, NJ, USA.

24. Brown, J.D., Goekjian, G., Poulson, R., Valeika, S. and Stallknecht, D.E. (2009) Avian influenza virus in water Infectivity is dependent on $\mathrm{pH}$, salinity and temperature. Vet. Microb., 136(1-2): 20-26.

25. Muhmmad, K., Das P., Yaqoob, T., Riaz, A. and Manzoor, R. (2001) Effect of physico-chemical factors on survival of avian influenza virus (H7N3 type). Int. J. Agri. Bio., 3(4): 416-418.

26. Shahid, M.A., Abubakar, M., Hameed, S. and Hassan, S. (2009) Avian influenza virus (H5N1); effects of physico-chemical factors on its survival. Virol. J., 6(1): 38 .

27. Shoham, D., Jahangir, A., Ruenphet, S. and Takehara, K. (2012) Persistence of avian influenza viruses in various artificially frozen environmental water types. Influenza Res. Treat., 201: 1-11.

28. Puri, A., Body, F.P., Doms, R.W., White, J.M. and Blumenthal, R. (1990) Conformational changes and fusion activity of influenza virus hemagglutinin of the $\mathrm{H} 2$ and H3 subtypes Effects of acid pre-treatment. J. Virol., 64(8): 3824-3832.

29. Wanaratana, S., Tantilertcharoen, R., Sasipreeyajan, J. and Pakpinyo, S. (2010) The inactivation of avian influenza virus subtype H5N1 isolated from chickens in Thailand by chemical and physical treatments. Vet. Microbial., 140(1-2): 43-48.

$* * * * * * * *$ 